\title{
Light Source Problem Identified
}

National Cancer Institute

\section{Source}

National Cancer Institute. Light Source Problem Identified. NCI Thesaurus. Code

C139502.

Problems with the optical properties of a device such as diopter, glare, and irradiance or glistening. 